\title{
PERKEMBANGAN HABITS OF MIND MAHASISWA SELAMA MENGIKUTI PERKULIAHAN KEANEKARAGAMAN TUMBUHAN DENGAN PROGRAM PEMBELAJARAN INKUIRI BERORIENTASI ENTREPRENEURSHIP
}

\author{
Muhammad Syaipul Hayat ${ }^{1}$, Nuryani Y. Rustaman², Adi Rahmat ${ }^{2}$, Sri Redjeki² \\ ${ }^{1}$ Program Studi Pendidikan Biologi FPMIPATI Universitas PGRI Semarang, Jl. Sidodadi Timur No 24, Dr. \\ Cipto - Semarang, Indonesia \\ 2 Program Studi Pendidikan IPA, Sekolah Pascasarjana Universitas Pendidikan Indonesia, Jl. Dr.Setiabudi No. \\ 229, Bandung 40154, Indonesia \\ e-mail: fullsmile_84@student.upi.edu
}

\begin{abstract}
Biological learning should be able to transform biological content as knowledge as well as to optimize the potential of the content to be utilized in real life. To accommodate these goals learning should be oriented in the future in a sustainable manner (life-long learning). Therefore, in this paper the author examines the research results on the development of student life-long learning, especially Habits of mind during the lectures on Plant Diversity with entrepreneurship-oriented inquiry learning programs. This research involved 31 of $5^{\text {th }}$ semester undergraduate students in biology Education Department in one teachers college in Central Java. Data were collected using questionnaires and observation sheets which were arranged in the form of the Habits of mind rubric, which is a development of Marzano's framework life-long learning with three aspects, that is: self regulation, critical thinking, and creative thinking. The results of the study show that the average Habits of mind score of students has developed, from 2.68 to 3.28 from a total score of 4.00 . The data is reinforced by the findings of observation activities during the learning process. On average the Habits of mind of students based on the results of observations shows progress at each stage, that is stage I (2.23), stage II (2.58), stage III (3.18), and stage IV (3.55). In accordance with the development of the Habits of mind data which is shown in every aspect, the three aspects show significant development. Thus it can be concluded that entrepreneurshiporiented inquiry learning programs applied to Plant Diversity course can improve student Habits of mind well.
\end{abstract}

Keywords: habits of mind, inquiry, entrepreneurship, plant diversity

\begin{abstract}
Abstrak
Pembelajaran biologi harus mampu bertransformasi tidak hanya sekedar menjadikan konten biologi sebagai pengetahuan, akan tetapi mampu mengoptimalkan potensi dari konten tersebut untuk dimanfaatkan dalam kehidupan dunia nyata. Untuk mengakomodasi tujuan tersebut pembelajaran harus berorientasi pada masa yang akan datang secara berkelanjutan (lifelong learning). Oleh karenanya, pada makalah ini penulis mengkaji hasil penelitian tentang perkembangan lifelong learning mahasiswa, khususnya Habits of mind selama mengikuti perkuliahan Keanekaragaman Tumbuhan dengan program pembelajaran inkuiri berorientasi entrepreneurship. Penelitian ini dilakukan pada mahasiswa semester V Program Studi Pendidikan Biologi di salah satu LPTK di Jawa Tengah, dengan jumlah sampel 31 orang. Data dijaring dengan menggunakan kuesioner dan lembar observasi dalam bentuk rubrik Habits of mind yang diadaptasi dari framework lifelong learning Marzano. Ada delapan item pada rubrik tersebut yang merepresentasikan data tentang Habits of mind yang terdiri dari tiga aspek, yaitu: self regulation, critical thinking, dan creative thinking. Hasil penelitian menunjukkan bahwa skor rata-rata Habits of mind mahasiswa mengalami perkembangan, yaitu data yang dihimpun sebelum diberikan program adalah 2,68; dan data setelah diberikan program adalah 3,28 dari skor total 4,00. Data tersebut diperkuat dengan hasil temuan pada kegiatan observasi selama proses pembelajaran. Secara rata-rata Habits of mind mahasiswa berdasarkan hasil observasi menunjukkan perkembangan pada setiap
\end{abstract}


tahapnya, yaitu tahap I $(2,23)$, tahap II $(2,58)$, tahap III $(3,18)$, dan tahap IV $(3,55)$. Demikian juga dengan data perkembangan Habits of mind yang ditunjukkan pada setiap aspeknya, ketiga aspek menunjukkan perkembangan secara signifikan. Dengan demikian dapat disimpulkan bahwa program pembelajaran inkuiri berorientasi entrepreneurship yang diterapkan pada mata kuliah Keanekaragaman Tumbuhan dapat mengembangkan Habits of mind mahasiswa dengan baik.

Keywords: habits of mind, inkuiri, entrepreneurship, keanekaragaman tumbuhan

\section{PENDAHULUAN}

Objek-objek biologi memiliki potensi besar untuk mendukung kebutuhan hidup manusia. Bidang kajian tumbuhan adalah salah satu rumpun ilmu biologi yang kaya akan potensi alam, setiap spesies dari tumbuhan bahkan memiliki nilai untuk dikembangkan dalam konsep wirausaha. Akan tetapi jika tidak dikelola dengan baik potensi dari spesies tumbuhan tersebut akan disalahgunakan, sehingga menyebabkan ketidakseimbangan bagi lingkungan. Oleh karenanya, pendidikan harus hadir dalam mengantisipasi masalah tersebut dengan menawarkan konsep pembelajaran yang berorientasi pada masa yang akan datang (lifelong learning). Pembelajaran yang mampu mengoptimalkan potensi dari objek biologi tanpa bertujuan mengeksploitasi, akan tetapi bervisi pada pelestarian untuk mempersiapkan kehidupan bagi generasi yang akan datang.

Inkuiri adalah strategi yang relevan untuk pembelajaran biologi, karena dalam proses pembelajarannya melibatkan aktivitas-aktivitas yang sesuai dengan konsep-konsep biologi, seperti: pengamatan, mengajukan pertanyaan, investigasi; peninjauan terhadap bukti percobaan, pengumpulan dan penafsiran data, mengusulkan jawaban, memberi penjelasan, memprediksi; dan mengkomunikasikan hasil (NRC, 1996). Bahkan dalam sains khususnya biologi inkuiri bukanlah istilah yang asing, karena hakikat dari sains adalah inkuiri itu sendiri (Rustaman, 2005). Artinya, hakikat sains memiliki kesamaan prinsip dengan inkuiri. Hakikat dari sains adalah proses, produk dan nilai/ sikap (Toharudin et al., 2011). Akan tetapi, inkuiri saja tidak cukup untuk mengatasi permasalahan di atas. Oleh karenanya, dalam penelitian ini inkuiri diintegrasikan dengan nilai-nilai entrepreneurship. Hal tersebut bertujuan agar mahasiswa dalam belajar biologi tidak hanya terlibat dalam kegiatan saintifik saja, akan tetapi juga mengarahkan konsep-konsep biologi (seperti keanekaragaman tumbuhan) pada pemanfaatannya untuk kehidupan sehari-hari. Lebih dari itu, mahasiswa menjadi lebih memiliki kesadaran untuk melestarikan sumber daya alam hayati yang berorientasi pada pembangunan yang berkelanjutan.

Kebutuhan akan pengembangan keterampilan yang berkelanjutan akan terus dirasakan oleh setiap orang dari segala usia karena banyak pekerjaan di masa depan yang tidak ada saat ini (Cummins \& Kunkel, 2015). Sebagian ahli sains berpendapat bahwa pembelajaran sains, khususnya biologi yang lebih menekankan pada penguasaan konsep tanpa pembekalan lifelong learning turut memperparah kondisi yang tidak menjanjikan meski memiliki ijazah pada pelbagai level pendidikan, sehingga menantang para pendidik calon guru dan praktisi pendidikan untuk mencari solusinya (Rustaman, 2016).

Lifelong learning telah menjadi kata kunci di hampir semua negara karena pengaruhnya yang semakin besar pada kebijakan pendidikan di dunia global (Regmi, 2015), bahkan saat ini telah menjadi agenda pembangunan internasional (Preece, 2013). Sebagai contoh, di Singapura lifelong learning menjadi topik besar dalam wacana sumber daya manusia, pekerjaan, wirausaha dan pendidikan nasional. Bahkan pemerintah telah menerapkan lifelong learning dalam pendidikan sebagai strategi untuk bertahan hidup di negara ini (Ng, 2013). Di negara lain seprti China, lifelong learning telah menjadi fenomena global yang secara signifikan mengubah bentuk dasar sistem pendidikan nasional secara konvensional. Lifelong learning di China berpotensi untuk menawarkan perubahan nyata pada tujuan sosial yang dipertahankan sampai 
tingkat tertentu (Wang et al., 2017). Sementara di Eropa, lifelong learning adalah prioritas Uni Eropa yang sudah berlangsung lama, dengan penekanan pada kebutuhan utama yang dikejar semua orang (Ingham et al., 2016).

Lifelong learning harus memiliki tujuan untuk pembelajaran yang bermakna dan menyenangkan. Hal tersebut sebagaimana dikemukakan oleh $\mathrm{Li}$ (2016) dalam laporan penelitiannya bahwa pembelajaran transformatif mahasiswa adalah hasil dari kebahagiaan, kegembiraan, kesuksesan, dan disposisi transformatif untuk lifelong learning serta berbagai tantangan, penderitaan dan kesulitannya. Penelitian lain yang dilakukan oleh Shan (2017) di China mengemukakan bahwa lifelong learning telah diposisikan secara pragmatis untuk mendukung proyek pembangunan modernis negara tersebut, yang berpuncak pada proklamasi untuk beralih dari "made in China," yaitu ekonomi berbasis manufaktur, menjadi "created in China", yaitu ekonomi berbasis pengetahuan.

Pada framework lifelong learning Marzano (1994) terdapat lima standar, yaitu: complex thinking, information processing, effective communication, collaboration/ cooperation, habits of mind. Dalam makalah ini pembahasan difokuskan pada habits of mind standard. Pada standar ini terdapat tiga aspek di dalamnya, yaitu: self regulation, critical thinking, dan creative thinking. Dalam implementasinya, ketiga aspek tersebut diukur berdasarkan program yang dikembangkan, yaitu pembelajaran inkuiri berorientasi entrepreneurship yang diterapkan pada mata kuliah keanekaragaman tumbuhan. Adapun program pembelajaran yang dikembangkan merupakan integrasi antara prinsip inkuiri (Bybee, 2009) dan nilai-nilai entrepreneurship (Consortium for Entrepreneurship Education, 2004) yang diadaptasikan pada mata kuliah keanekaragaman tumbuhan. Berdasarkan permasalahan tersebut, pembahasan difokuskan pada bagaimana perkembangan habits of mind mahasiswa selama mengikuti perkuliahan keanekaragaman tumbuhan dengan program pembelajaran inkuiri berorientasi entrepreneurship.

\section{METODE}

Makalah ini merupakan bagian dari penelitian pengembangan tentang program pembelajaran inkuiri berorientasi entrepreneurship pada kajian tumbuhan untuk membekalkan lifelong learning mahasiswa. Data yang disajikan pada makalah ini merupakan data implementasi tahap I (satu) yang difokuskan pada perkembangan Habits of mind mahasiswa setelah mengikuti perkuliahan Keanekaragaman Tumbuhan. Adapun Habits of mind adalah salah satu standar pada framework Lifelong learning Marzano (Marzano et al., 1994) yang diukur dalam penelitian ini. Program yang dikembangkan disusun ke dalam empat tahap pembelajaran. Pada setiap tahap pembelajaran dirancang dengan sintaks inkuiri 5E (engagement, exploration, explain, elaboration, and evaluation) yang diintegrasikan dengan nilai-nilai entrepreneurship. Adapun nilai-nilai entrepreneurship diterapkan secara berjenjang pada setiap tahapnya, yaitu: tahap 1, nilai-nilai entrepreneurship yang ditanamkan adalah keterampilan dasar, seperti: sifat/ perilaku wirausaha dan penemuan konsep wirausaha; tahap II, nilai-nilai entrepreneurship yang diintegrasikan berupa keterampilan pengembangan, seperti: pengembangan konsep wirausaha dan penyiapan sumber daya; tahap ketiga disebut sebagai tahap advance, karena keterampilan entrepreneurship yang diterapkan berupa keterampilan penguatan, seperti: literasi ekonomi \& keuangan, serta manajemen usaha; dan tahap keempat adalah tahap professional, keterampilan entrepreneurship yang dibekalkan adalah manajemen pemasaran dan keterampilan digital. Keempat tahap pembelajaran tersebut diintegrasaikan dengan nilai-nilai entrepreneurship yang diadaptasi dari CEE (Consortium for Entrepreneurship Education, 2004).

Subjek penelitian yang terlibat dalam penelitian ini adalah 31 mahasiswa yang mengikuti mata kuliah Keanekaragaman Tumbuhan pada semester 5 Program Studi Pendidikan Biologi pada salah satu LPTK di Jawa Tengah. Instrumen yang digunakan untuk menjaring 
data dalam penelitian ini adalah kuesioner dan lembar observasi yang disusun dalam bentuk rubrik Habits of mind, yang merupakan pengembangan dari framework lifelong learning Marzano's (Marzano et al., 1994). Ada delapan item pada rubrik tersebut yang merepresentasikan data tentang Habits of mind yang terdiri dari tiga aspek, yaitu: self regulation, critical thinking, dan creative thinking. Ketiga aspek tersebut merpakan data yang akan diukur perkembangannya selama mahasiswa mengikuti perkuliahan Keanekaragaman Tumbuhan. Rubrik pada kuesioner dan lembar observasi disusun dalam bentuk skala rating 4, 3, 2, 1 dengan deskripsi sesuai konten pada item butir rubriknya masing-masing.

Teknik pengambilan data pada kuesioner dilakukan dengan dua kali pengukuran, yaitu pengukuran awal (pre) yang diambil sebelum implementasi program dan pengukuran akhir (post) diambil setelah implementasi program secara self assessment. Setiap mahasiswa diminta untuk memilih satu dari empat pernyataan yang merepresentasikan keadaan dirinya terhadap setiap item pada rubrik kuesioner Habits of mind yang diberikan. Adapun lembar observasi digunakan sebagai instrumen untuk mengamati perkembangan Habits of mind mahasiswa pada setiap pertemuan dalam perkuliahan Keanekaragaman Tumbuhan selama pengambilan data. Teknik penjaringan data dilakukan oleh satu orang observer yang mengamati kinerja mahasiswa pada masing-masing kelompok, dan subjek penelitian dibagi kedalam enam kelompok.

Data yang telah dihimpun dari kuesioner selanjutnya dianalisis secara kuantitatif dengan menghitung rata-rata total dan rata-rata masing-masing aspek Habits of mind. Kemudian diinterpretasikan dalam bentuk diagram perbandingan antara kondisi awal dan kondisi akhir. Adapun data yang dihimpun melalui lembar observasi dianalisis dengan melihat perkembangan Habits of mind pada setiap tahapan pembelajarannya, baik perkembangan total maupun perkembangan pada setiap aspek Habits of mind (self regulation, critical thinking, dan creative thinking). Selanjutnya dilakukan triangulasi dari keseluruhan data yang telah dihimpun agar diperoleh interpretasi data secara komprehensif.

\section{HASIL DAN PEMBAHASAN}

Data hasil penelitian yang telah dihimpun selanjutnya dideskripsikan dan diinterpretasikan ke dalam dua bagian, yaitu: 1) kondisi Habits of mind mahasiswa sebelum dan setelah diberikan program, yang dijaring dengan menggunakan kuesioner; 2) perkembangan Habits of mind mahasiswa pada setiap tahap pembelajaran, yang dijaring melalui observasi.

\section{Kondisi awal dan akhir Habits of mind Mahasiswa}

Berikut ditunjukkan data tentang kondisi Habits of mind mahasiswa sebelum dan setelah diberikan program pembelajaran yang dikembangkan. Pertama-tama diilustrasikan kondisi Habits of mind secara keseluruhan, yaitu sebagaimana ditunjukkan pada Gambar .

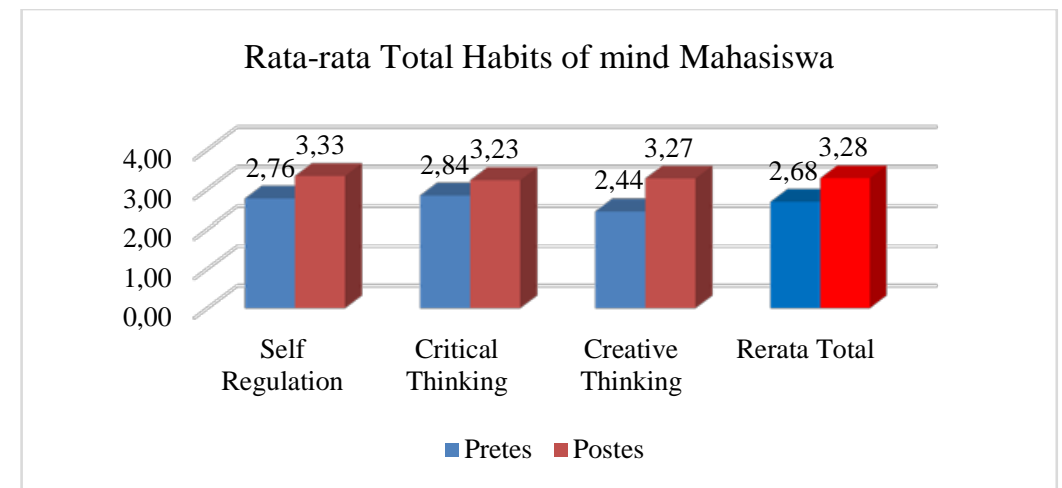

Gambar 1. Data Habits of mind Mahasiswa secara keseluruhan 
Pada Gambar 1 ditunjukkan bahwa secara keseluruhan rata-rata Habits of mind mahasiswa mengalami peningkatan dari keadaan sebelum $(2,68)$ dan setelah diberikan program $(3,28)$ dari skor maksimal 4,00. Berdasarkan data tersebut dapat diartikan bahwa program pembelajaran yang dikembangkan memberikan dampak positif terhadap perkembangan Habits of mind mahasiswa.

Gambar 1 juga menjelaskan lebih rinci bahwa seluruh aspek Habits of Mind mengalami peningkatan. Akan tetapi, dari ketiga aspek tersebut yang menunjukkan peningkatan paling tinggi adalah aspek self regulation, yaitu dengan skor akhir 3,33, sedangkan aspek critical thinking 3,23, dan aspek creative thinking adalah 3,27 dari skor total 4,00. Selisih skor dari ketiga aspek tersebut memang tidak berbeda signifikan, akan tetapi dapat diinterpretasikan bahwa selama proses pembelajaran mahasiswa menjadi lebih menyadari kebutuhan belajarnya, seperti: menyiapkan perencanaan yang matang, sadar akan sumber daya yang dibutuhkan, dan peka terhadap umpan balik.

Secara spesifik data hasil pengukuran Habits of mind dapat dideskripsikan berdasarkan aspeknya masing-masing. Hasil pengukuran pada aspek pertama (self regulation) dijelaskan pada Gambar 2.

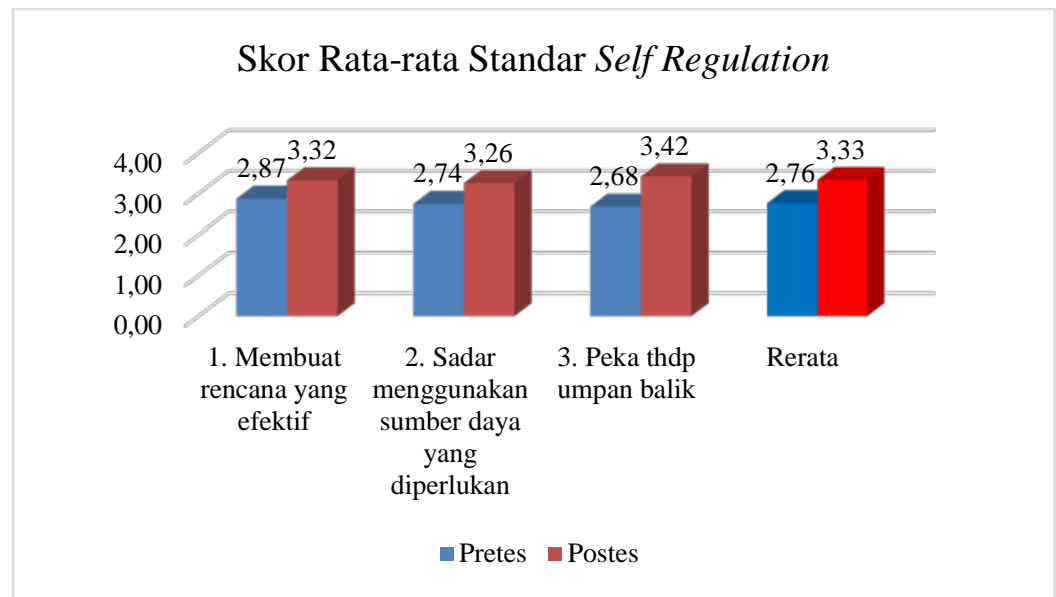

Gambar 2. Skor Rata-rata Standar Self regulation

Berdasarkan data pada Gambar 2 ditunjukkan bahwa secara keseluruhan skor rata-rata aspek self regulation mengalami perkembangan dari kondisi awal $(2,76)$ dan kondisi akhir setelah diberikan program pembelajaran (3,33). Lebih rinci Gambar 2 mendeskripsikan kondisi Habits of Mind mahasiswa per indikator. Ketiga indikator Habits of Mind pada aspek self regulation (membuat rencana yang efektif, sadar menggunakan sumber daya yang diperlukan, peka terhadap umpan balik) seluruhnya menunjukkan perkembangan. Akan tetapi, dari ketiganya skor yang paling tinggi adalah indikator peka terhadap umpan balik. Data tersebut dapat diinterpretasikan bahwa mahasiswa menjadi lebih peka terhadap umpan balik dari dosen maupun teman sejawatnya selama proses pembelajaran.

Aspek kedua dari standar Habits of mind yang diukur dalam penelitian ini adalah critical thinking. Kondisi perkembangan habits of mind dari aspek ini dijelaskan pada Gambar 3.

Gambar 3 mengilustrasikan perkembangan kondisi Habits of mind mahasiswa yang ditunjukkan pada aspek critical thinking, yaitu kondisi awal menunjukkan skor 2,84, sedangkan kondisi akhir setelah diberikan program pembelajaran menjadi 3,23. Perkembangan tersebut ditunjukkan juga oleh setiap indikator pada aspek ini. Akan tetapi, dari kedua indikator yang menunjukkan perkembangan paling baik adalah indikator "Peka terhadap perasaan dan tingkat pengetahuan orang lain", yaitu skor akhir 3,45; sedangkan indikator "mengatasi impulsif" skor akhirnya hanya 3,13. Artinya, selama proses pembelajaran berlangsung 
mahasiswa menjadi terlatih untuk lebih peka terhadap perasaan dan tingkat pengetahuan orang lain. Kondisi tersebut dibuktikan dengan kebiasaan mahasiswa dalam berdiskusi dan presentasi hasil kerja di kelas menjadi lebih berhati-hati dalam menyampaikan pendapatnya, satu sama lain saling menunjukkan rasa hormat dan saling menghargai.

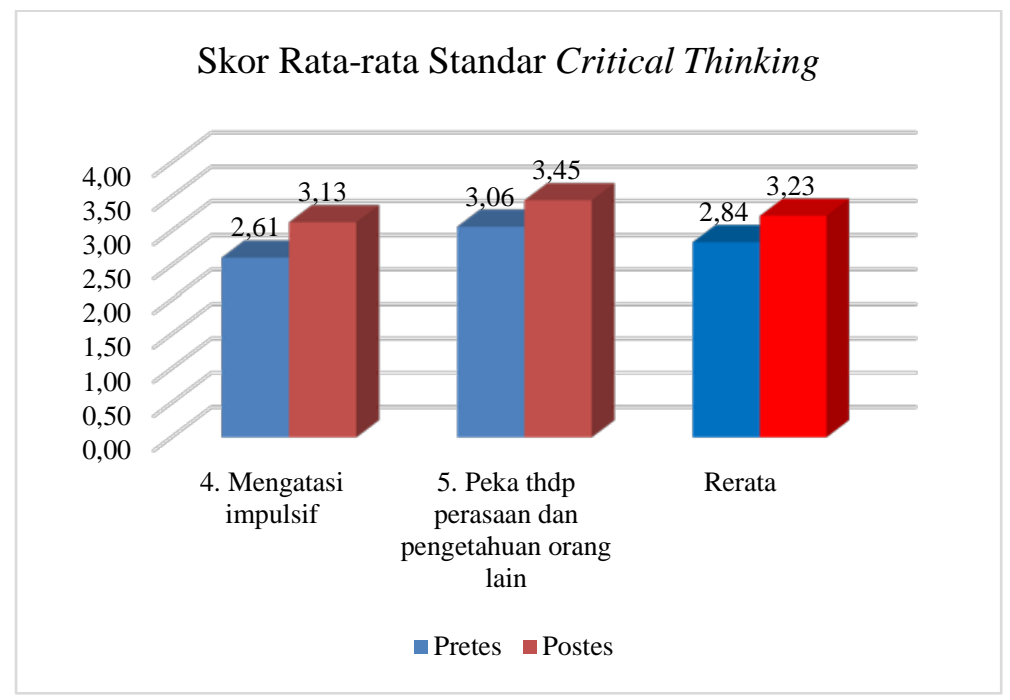

\section{Gambar 3. Skor Rata-rata Standar Critical thinking}

Aspek ketiga dari Habits of mind adalah creative thinking. Terdapat tiga indidkator pada aspek ini, dan ketiganya menunjukkan perkembangan secara positif. Lebih rinci deskripsi dari kondisi Habits of mind mahasiswa pada aspek creative thinking dijelaskan pada Gambar 4.

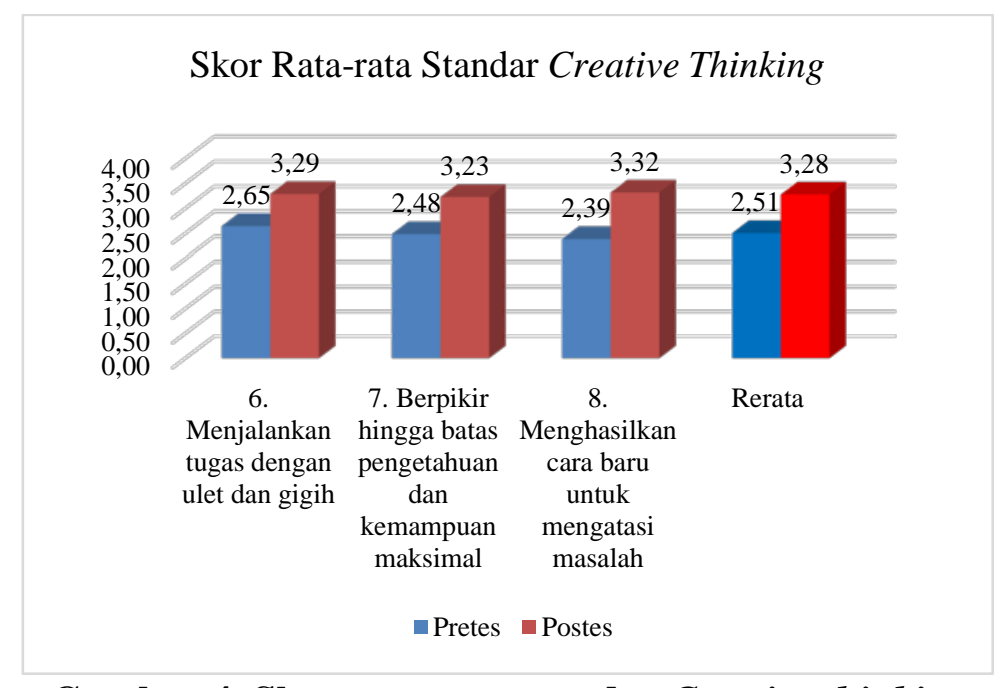

Gambar 4. Skor rata-rata standar Creative thinking

Secara rata-rata data yang ditunjukkan oleh Gambar 4 mengilustrasikan perkembangan Habits of mind mahasiswa pada aspek creative thinking yang sangat baik, yaitu skor awal hanya 2,44 dan skor akhir setelah diberikan program pembelajaran mencapai 3,27. Perkembangan angka tersebut merupakan yang paling tinggi diantara aspek lainnya, walaupun skor akhirnya masih lebih tinggi aspek self regulation. Kondisi ini menginterpretasikan bahwa selama proses pembelajaran, program yang dikembangkan mampu melatihkan keterampilan berpikir kreatif dengan baik pada diri mahasiswa. Setelah diberikan program yang dikembangkan, mahasiswa menjadi lebih ulet dan berjiwa pantang menyerah, mampu berpikir hingga batas kebiasaan dan pengetahuan dirinya, serta mampu menghasilkan cara baru di atas kondisi standar. 
Analisis tersebut relevan dengan beberapa temuan dari hasil penelitian sebelumnya. Pendekatan pedagogis dalam pembelajaran entrepreneurship memainkan peran penting dalam mengubah perilaku kreatif siswa, dan secara efektif memotivasi mereka untuk berpartisipasi aktif dalam kerja tim, serta mampu menghasilkan nilai baru bagi timnya (Gundry et al., 2014). Siswa yang menganggap dirinya memiliki persepsi kreativitas yang lebih tinggi memiliki kecenderungan belajar yang lebih tinggi, dan individu kreatif juga menilai hasil belajarnya sebagai hal yang positif baik manfaat maupun kemudahan penggunaan yang dirasakannya (Lourenc \& Jayawarna, 2011). Nilai kreativitas dan pengalaman wirausaha siswa sangat ditentukan oleh niat wirausaha, dan persepsi siswa terhadap risiko atau dampak yang ditimbulkan memberikan pengaruh negatif terhadap niat wirausaha siswa (Hamidi et al., 2008).

\section{Perkembangan Habits of mind mahasiswa pada setiap tahap pembelajaran}

Data perkembangan Habits of mind yang telah ditunjukkan pada poin 1 yang dihimpun melalui kuesioner diperkuat dengan hasil observasi yang dilakukan sepanjang proses pembelajaran pada setiap tahapnya. Data perkembangan habits of mind mahasiswa pada setiap tahap pembelajaran dideskripsikan pada Tabel 1.

Tabel 1. Data perkembangan habits of mind pada setiap tahap pembelajaran

\begin{tabular}{|c|c|c|c|c|c|}
\hline \multirow{2}{*}{ No } & \multirow{2}{*}{ Aspek } & \multicolumn{4}{|c|}{ Tahap Pembelajaran } \\
\hline & & 1 & 2 & 3 & 4 \\
\hline \multicolumn{6}{|c|}{ Standar Self regulation } \\
\hline 1 & Membuat rencana yang efektif & 2.43 & 2.62 & 3.26 & 3.58 \\
\hline 2 & Sadar menggunakan sumber daya yang diperlukan & 2.43 & 2.78 & 3.24 & 3.67 \\
\hline \multirow[t]{2}{*}{3} & Peka terhadap umpan balik & 2.39 & 2.68 & 3.45 & 3.64 \\
\hline & Skor rata-rata & 2.42 & 2.69 & 3.32 & 3.63 \\
\hline \multicolumn{6}{|c|}{ Standar Critical thinking } \\
\hline 4 & Mengatasi impulsif & 1.84 & 2.25 & 2.74 & 3.39 \\
\hline \multirow[t]{2}{*}{5} & Peka thdp perasaan dan pengetahuan orang lain & 2.32 & 2.61 & 3.09 & 3.32 \\
\hline & Skor rata-rata & 2.08 & 2.43 & 2.92 & 3.36 \\
\hline \multicolumn{6}{|c|}{ Standar Creative thinking } \\
\hline 6 & Menjalankan tugas dengan ulet dan gigih & 2.48 & 2.82 & 3.58 & 3.84 \\
\hline 7 & $\begin{array}{l}\text { Berpikir hingga batas pengetahuan dan kemampuan } \\
\text { maksimal }\end{array}$ & 2.25 & 2.54 & 3.36 & 3.74 \\
\hline \multirow[t]{2}{*}{8} & Menghasilkan cara baru untuk mengatasi masalah & 1.66 & 2.33 & 2.80 & 3.33 \\
\hline & Skor rata-rata & 2.13 & 2.56 & 3.25 & 3.64 \\
\hline \multicolumn{2}{|r|}{ Skor Total } & 2.23 & 2.58 & 3.18 & 3.55 \\
\hline
\end{tabular}

Data pada Tabel 1 mengilustrasikn bahwa secara rata-rata Habits of mind mahasiswa menunjukkan perkembangan pada setiap tahapnya, yaitu tahap I $(2,23)$, tahap II $(2,58)$, tahap III $(3,18)$, dan tahap IV $(3,55)$. Demikian juga dengan data perkembangan Habits of mind yang ditunjukkan pada setiap aspeknya, ketiga aspek menunjukkan perkembangan secara signifikan. Berdasarkan data pada Tabel 1 menunjukkan bahwa setiap aspek Habits of mind mengalami perkembangan, akan tetapi dari ketiganya yang paling menunjukkan perkembangan adalah aspek creative thinking, yaitu: tahap I $(2,13)$, tahap II $(2,56)$, tahap III $(3,25)$, dan tahap IV $(3,64)$. Aspek self regulation perkembangannya sedikit berada di bawahnya, yaitu: tahap I $(2,42)$, tahap II $(2,69)$, tahap III $(3,32)$, dan tahap IV $(3,63)$. Sementara aspek critical thinking 
menunjukkan perkembangan paling rendah dibandingkan kedua aspek lainnya, yaitu: tahap I $(2,08)$, tahap II $(2,43)$, tahap III $(2,92)$, tahap IV $(3,36)$.

Kondisi data yang ditunjukkan pada Tabel 1 tersebut menginterpretasikan bahwa antara data yang dihimpun melalui observasi sejalan dengan data yang dijaring melalui kuesioner. Keduanya menunjukkan fakta yang sama yaitu perkembangan Habits of mind pada aspek creative thinking jauh lebih berkembang dengan baik selama proses pembelajaran dengan program yang dikembangkan. Fakta tersebut mengindikasikan bahwa program pembelajaran inkuiri berorientasi entrepreneurship yang diterapkan pada mata kuliah Keanekaragaman Tumbuhan berhasil melatih keterampilan berpikir kreatif pada diri mahasiswa.

Beberapa analisis yang dapat diberikan terkait hasil temuan data penelitian ini, antara lain: 1) perkuliahan keanekaragaman tumbuhan yang disusun dengan program yang dikembangkan tidak hanya dilakukan dengan mengidentifikasi dan mengklasifikasikan spesies berdasarkan taksonnya, akan tetapi juga diarahkan pada pengembangan konsep wirausaha dari potensi yang dimiliki oleh spesies yang diamati. Pengalaman tersebut membekali mahasiswa untuk menghasilkan cara baru dalam melihat situasi di luar batas-batas konvensi standar; 2) program yang dikembangkan dirancang dengan beberapa tahapan (empat tahap) berdasarkan tingkat kesulitan dari keterampilan entrepreneurship dan indikator lifelong learning yang diintegrasikan dalam pembelajaran. Dengan adanya tahap-tahap pembelajaran tersebut mendorong mahasiswa untuk berpikir hingga batas maksimal pengetahuan dan kemampuan dirinya; 3) konsep yang dibangun dalam program yang dikembangkan adalah manjadikan objek biologi sebagai sumber belajar untuk menemukan pengetahuan, sehingga dengan demikian mahasiswa tidak terlalu ketergantungan pada smartphone nya ketika mencari referensi akan tetapi berusaha membangun pengetahuan berdasarkan objek yang diamati. Dengan demikian lahir kemandirian pada diri mahasiswa untuk lebih tekun dalam bekerja walaupun terdapat banyak hambatan, bahkan tidak segera menemukan jawaban dari masalah yang dihadapi.

Beberapa penelitian sebelumnya mengatakan bahwa Habits of mind mahasiswa meningkat dengan baik dalam perkuliahan kapita selekta biologi melalui pembelajaran yang banyak memberikan permasalahan-permasalahan konsep kepada mahasiswa (Gloria, 2017). Habits of mind mahasiswa berkembang dengan baik setelah diberikan asesmen formatif secara intensif selama pembelajaran, mahasiswa diberikan feedback, self-assessment dan peer assessment secara berkala (Sriyati et al., 2010). Penelitian lain menyebutkan bahwa program perkuliahan Anatomi Tumbuhan berbasis dimensi Belajar Marzano dapat meningkatkan literasi kuantitatif dan Habits of mind mahasiswa (Nuraeni et al., 2015).

\section{KESIMPULAN}

Habits of mind mahasiswa mengalami perkembangan dengan baik selama perkuliahan Keanekaragaman Tumbuhan dengan program pembelajaran inkuiri berorientasi entrepreneurship. Fakta tersebut dibuktikan dengan hasil pengukuran awal dan akhir melalui kuesioner yang diisi oleh mahasiswa masing-masing. Selain itu, data didukung oleh hasil observasi selama pembelajaran dalam empat tahap. Dari ketiga aspek habits of mind yang diukur dalam penelitian ini, seluruhnya menunjukkan perkembangan dengan baik, akan tetapi aspek creative thinking menunjukkan perkembangan lebih tinggi. Hal tersebut disebabkan karena keterampilan berpikir kreatif mahasiswa menjadi terlatih dengan konsep perkuliahan keanekaragaman tumbuhan yang diorientasikan pada nilai-nilai entrepreneurship.

\section{UCAPAN TERIMA KASIH}

Terima kasih kepada LPDP (Lembaga Penyandang Dana Pendidikan) dan BUDI-DN (Beasiswa Unggulan Dosen Indonesia Dalam Negeri) yang telah mendukung beasiswa secara 
penuh kepada penulis selama menempuh studi doktoral. Kedua, ucapan terima kasih kepada seluruh pihak yang telah membantu dalam pengumpulan data penelitian.

\section{DAFTAR PUSTAKA}

Bybee, R. W. 2009. The Bscs 5e Instructional Model And $21^{\text {st }}$ Century Skills. Biological Sciences Curriculum Study (BSCS): The National Academies.

Consortium for Entrepreneurship Education. 2004. The National Content Standars for Entrepreneurship Education.

Cummins, P. \& Kunkel, S. 2015. A Global Examination of Policies and Practices for Life-long learning. New Horizons in Adult Education \& Human Resource Development, 27(3), 317.

Gloria, R. Y. 2017. Efektivitas Pembelajaran Kapita Selekta Biologi Berbasis Masalah Untuk Membentuk Habits of mind Mahasiswa Calon Guru. Scientiae Educatia: Jurnal Pendidikan Sains, 6(1). 8-14.

Gundry, L. K., Ofstein, L. F. \& Kickul, J. R. 2014. Seeing around corners: How creativity skills in entrepreneurship education influence innovation in business. The International Journal of Management Education, 12 (3). 529-538.

Hamidi, D. Y., Wennberg, K. \& Berglund, H. 2008. Creativity in entrepreneurship Education. Journal of Small Business and Enterprise Development, 15 (2). Pp 304-320.

Ingham, H., Ingham, M. \& Afonso, J. A. 2016. Participation in life-long learning in Portugal and the UK Education Economics, 25 (4). 266-289.

Li, M. 2016. Developing Skills and Disposition for Lifelong learning: Acculturative Issues Surrounding Supervising International Doctoral Students in New Zealand Universities. Journal of International Students, 6 (3).

Lourenco, F. \& Jayawarna, D. 2011. Enterprise education: the effect of creativity on training outcomes. International Journal of Entrepreneurial Behaviour \& Research, 17 (3). 224-244.

Marzano, R. J., Pickering, D. \& McTighe, J. 1994. Assessing Student Outcomes: Performance Assessment Using the Dimension of Learning Model. Alexandria Virginia: Association for Supervision and Curriculum Development.

National Research Council. 1996. The National Science Education Standards. Washington DC: National Academic Press.

Ng, P. T. 2013. An examination of life-long learning policy rhetoric and practice in Singapore. Int. J. of Lifelong Education, 32 (3), 318-334.

Nuraeni, E., Redjeki, S., \& Rahmat, A. 2015. Perkembangan Literasi Kuantitatif Mahasiswa Biologi Dalam Perkuliahan Anatomi Tumbuhan Berbasis Dimensi Belajar. Jurnal Ilmu Pendidikan, 21(2), 127-135.

Preece, J. 2013. Africa and international policy making for life-long learning: Textual revelations. International Journal of Educational Development, 33, 98-105.

Regmi, K. D. 2015. Life-long learning: Foundational models, underlying assumptions and critiques. Int. Rev Educ., 61 (2), 133-151.

Rustaman, N. Y. 2005. Perkembangan penelitian pembelajaran berbasis inkuiri dalam pendidikan sains. Prosiding Seminar Nasional II. Himpunan Ikatan Sarjana dan Pemerhati Pendidikan IPA Indonesia bekerjasama dengan FPMIPA Universitas Pendidikan Indonesia.

Rustaman, N. Y. 2016. Pemberdayaan Entrepreneurship: Implementasi Teori-U dalam Bioteknologi Praktis Berbasis STEM. Pros. Seminar Nasional Sains dan Entrepreneurship III (Program Studi Pendidikan Biologi FPMIPATI Universitas PGRI Semarang). 
Shan, H. 2017. Lifelong Education and Lifelong learning with Chinese Characteristics: A Critical Policy Discourse Analysis. Asia Pacific Educ. Rev., 18.

Sriyati, S., Rustaman, N. Y. \& Zainul, A. 2010. Penerapan asesmen formatif untuk membentuk Habits of mind Mahasiswa Biologi. Seminar Nasional Biologi "Pembelajaran Sains dan Perkembangan Biologi di Era Molekuler” (pp. 1-14) Semarang, Indonesia: FPMIPA Universitas Negeri Semarang (UNNES).

Toharudin, U., Hendrawati, S. \& Rustaman, A. 2011. Membangun Literasi Sains Peserta Didik. Bandung: Humaniora.

Wang, M., Yuan, D. \& Weidlich, M. 2017. Do the demands of the global forces shape local agenda? An analysis of life-long learning policies and practice in China. Asia Pacific Educ. Rev., 18 (2). 219-226. 